\title{
Electrical resistivity structure at the North-Central Turkey inferred from three-dimensional magnetotellurics
}

Sinan Özaydın', Sabri Bülent Tank* and Mustafa Karaş ${ }^{1,2}$

\begin{abstract}
Magnetotelluric data analyses and three-dimensional modeling techniques were implemented to investigate the crustal electrical structure in the North-Central Turkey, along a 190-km-long profile crossing Çankırı Basin, İzmirAnkara-Erzincan Suture Zone and Central Pontides. In this area, the segment of the North Anatolian Fault (NAF) shows 280-km-long restraining bend, where it was near the focus of the hazardous 1943 Tosya Earthquake (M: 7.6). Structure around the NAF exhibits resistive characteristics at both sides of the fault reaching to at least $25 \mathrm{~km}$ of depth. Fluids below the brittle-ductile transition were not detected which will nucleate earthquakes in the area. This resistive structure implies an asperity zone of the NAF, which was ruptured in 1943. The presence of a fluid-bearing upwelling conductive anomaly in Central Pontides may suggest that beneath the deep brittle crust, there may exists a fluid-enriched conductive forearc region, which may have caused by a prograde source related to paleo-tectonic processes.
\end{abstract}

Keywords: Fluid, North Anatolian Fault, Magnetotellurics, Central Pontides, Electrical resistivity, Seismicity

\section{Introduction}

Major seismic features of the Anatolia follow the mechanically weak path of the Tethyside accretionary complexes (Şengör et al. 2005). The most hazardous of all, the NAF is known as a $1200-\mathrm{km}$-long dextral strike-slip fault zone that initiates at Karlıova Junction, lies along the Black Sea coast until it divides into several branches near Adapazarı (Şengör et al. 2005). Occurrence of large earthquakes along the NAF is known to be periodical with centennial cycles (Parsons et al. 2000), where the major earthquakes have the tendency to migrate to the west with a progressive failure mechanism (Stein et al. 1997). Seismicity along the NAF naturally does not show homogeneous characteristics due to complex geology and geodynamic state of the Anatolia. Many segments can be interpreted as seismic gaps (Ergintav et al. 2014), while the surface creep (Çakır et al. 2005) or microseismic activity (Örgülü

\footnotetext{
*Correspondence: bulent.tank@boun.edu.tr

${ }^{1}$ Kandilli Observatory and Earthquake Research Institute, Boğaziçi University, Istanbul, Turkey

Full list of author information is available at the end of the article
}

2011) is also valid explanations for release of stress. Karaş et al. (2017) showed that even in small distances within the same segment of the NAF, structures of faults might show drastically different characteristics, thus leading to heterogeneous rheological environments.

The presence of fluids in rocks can change the mechanical response of the medium by micro-cracking, hydrofracturing, inducing the pore connectivity and reducing the effective normal stress (Bürgmann and Dresen 2008). As a consequence, temporal and spatial fluid variations at crustal depths are proposed to influence the tectonic processes and earthquake generation (Rice 1992; Byerlee 1993; Sibson 2014). Aqueous saline fluids and partial melts within the rock matrix of geological formations could enhance the bulk conductivity of rocks by several orders of magnitude via ionic conduction. Magnetotelluric (MT) method is able to investigate the geo-electric structure up to several hundreds of kilometers depth and has proven to be capable in designing hypotheses for fluid-induced tectonic mechanisms (e.g., Ritter et al. 2005; Jiracek et al. 2007; Wannamaker et al. 2009; Unsworth 2010). 
Resistivity variations in the vicinity of the NAF and subsidiary systems were previously linked with seismic behavior by applying the MT method. Tank et al. (2005) investigated the resistivity structure along the western NAF branches and detected a deep lower-crustal conductor below the seismogenic zone. Spatial position of this conductor was interpreted to be related to the observed post-seismic creep and aftershock distribution along the segment after the 1999, İzmit Earthquake. Similar type of mechanism was observed beneath the Marmara Sea where the resistivity variations were found to be related to microseismic activity in the region (Kaya et al. 2013). Kaya et al. (2009) were able to image the resistive asperity zone and claimed that this zone was responsible for super-shear earthquake occurred along the Düzce Fault in 1999. Likewise, Ganos Fault, which appears as an anomalously quiescent seismic gap, depicted with resistive structures appearing at both sides of the fault, representing mechanically strong units (Karaş et al. 2017). Avşar et al. (2013) carried out a survey in Erzincan Basin and found a shallow conductor related to NAF. The seismogenic structure described in this study was demonstrated by resistive characteristics beneath the basin, where earthquakes tend to nucleate. Türkoğlu et al. (2015) compared the resistivity structures of the NAF and the East Anatolian Fault (EAF) in the Eastern Anatolia, where lower-crustal conductor of the NAF appears much less conductive compared to the one in the EAF. This difference between two sections was interpreted to stem from relative maturity difference between the faults, which might infer to transfer of strain localization to the upper crust with increasing age. A different interpretation pointed out by Türkoğlu et al. (2015) is that a fluid source might control the conductivity of these lowercrustal areas, which are possibly related to the paleo-tectonic events (e.g., subduction, delamination).

The study area was positioned where the NAF is characterized by a 280-km-long restraining bend, which accommodated large rupture events in the history (1668, 1943 Tosya M:7.6) (Hubert-Ferrari et al. 2002). The fault segment is constraint by two creeping segments on either side (Çakır et al. 2005; Karabacak et al. 2011) and has incoherent rupture propagation direction during the earthquake cycle of the last century on the NAF (Stein et al. 1997). All of these features point out the importance of revealing the crustal structure and fluid-distribution at this overtly complex region, where the current seismic nature could be highly inherited by its paleo-tectonic evolution. In terms of the resistivity structure, this study intends to reveal the tectonic properties of the area, which experienced closure of Paleo- and Neo-Tethys oceans, subduction, collision, extension, uplift and finally strike-slip faulting during its development (Kaymakçı et al. 2009; Okay et al. 2013). To achieve these goals, 25 wide-band (160-0.001 Hz) MT stations were deployed to form a profile crossing some of the significant features that defines the tectonic evolution of northern Anatolia, such as, Çankırı Basin, İzmir-Ankara-Erzincan Suture (IAES), the NAF, Central Pontides Supercomplex and the Pontide Arc (Fig. 1).

\section{Geological and tectonic setting of the study area}

Pontides are a mountain chain that had been built up as a tectonic unit, which were amalgamated onto active margin of Laurasian Continent. Central Pontides (CP) are the geographical term that describes the northwardly bended section of the Pontic Orogenic Belt and related tectonic structures. Most of the CP is made up of large metamorphic bodies that were produced due to tectonic amalgamation of Paleo-Tethyan accretionary materials (Fig. 1) (Okay et al. 2013). The northernmost one is the PermoTriassic Küre Complex (Okay et al. 2013). This unit is juxtaposed with Permo-Carboniferous granites, which collectively made up the continental basement of CP. In terms of their ages, there is a clear distinction between Küre Complex and the southern Mesozoic-aged metamorphic units, which are Kargı Massif, Domuzdağ and Çangaldağ complexes, renowned collectively as Central Pontides Supercomplex (CPS) (Okay et al. 2013). Today, the units that form the CPS are in contact with each other with north-dipping thrust faults and make up the Eurasian front of the Anatolian collision in CP.

Units related to the closure of Neo-Tethyan Ocean appear at the south of Paleo-Tethyan Metamorphic Sole and the NAF (Fig. 1). Northernmost one of these units is called the Kösdağ Formation, which is represented by mafic and felsic low-grade meta-volcanic rocks (Aygül et al. 2015). The whole sequence was thrusted by ophiolitic melanges, which forced the Kösdağ Arc units to become structurally positioned as a steeply dipping anticline (Aygül et al. 2015). Moving further southwards, another volcano-clastic unit Yaylaçayı Formation was situated with a younger geologic age of Upper-Cretaceous. Geochemical analyses of Kösdağ Arc suggest that it represents a supra-subduction zone intra-oceanic arc, which was later terminated due to the rollback of Neo-Tethyan Oceanic Lithosphere (Aygül et al. 2015).

South of the IAES, there lays the large Cenozoic Çankırı Basin surrounded by Neo-Tethyan Ophiolitic Melanges (NTOM). The thick sequence consists of continuous sedimentation since Upper-Cretaceous, making the basin quite significant for understanding the evolution of Neo-Tethyan realm in Turkey. While moving away from the center of the basin, stratigraphic structure becomes more complex at every direction, where thrust 


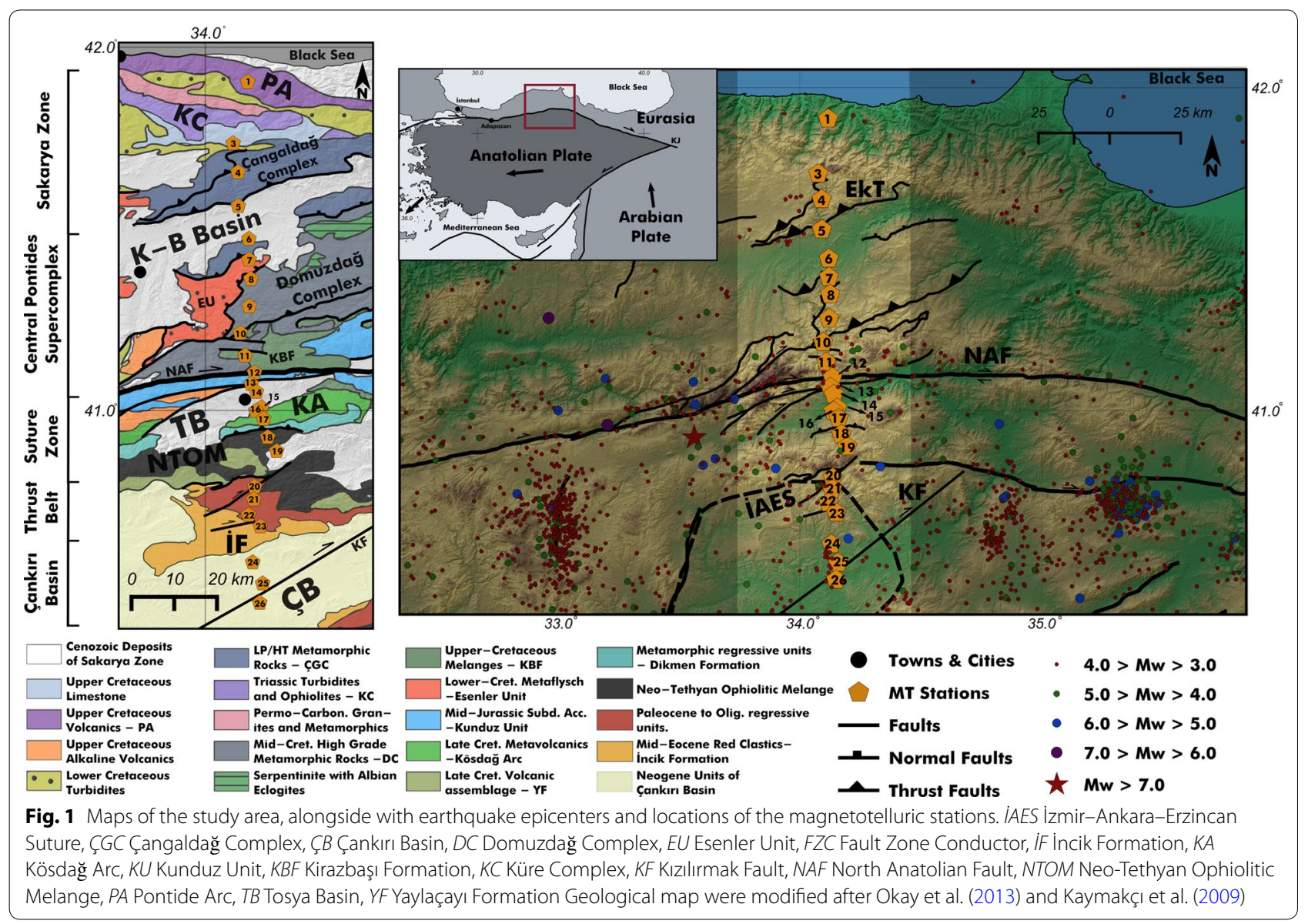

belts appear related to the Neo-Tethyan convergence in the area (Kaymakçı et al. 2009).

\section{Dimensionality analyses}

In this study, dimensional nature of the MT data was examined with the phase tensor (PT) method (Caldwell et al. 2004). Invariants of PT give out information on dimensionality of MT data depending on its frequency. They are conventionally represented by PT ellipses, where either of the two axes is oriented along the geoelectric strike angle. Extreme $\beta$ values indicate the existence of three-dimensional geo-electric features within the subsurface. Practically, above $3^{\circ}$ of deviation from zero is largely considered to be 3-D geo-electric environment (Booker 2014). Figure 2a, b shows rose diagrams of geo-electric strike orientations for three different regions and the PT pseudo-section for the whole data. Ellipses indicated with black-dashed lines are selected due to their higher ellipticities, which refers to highly polarized strike directions that should be observed around fault-like structures. These selected areas coincide well with traces of the fault zones found at different frequency ranges, where extreme $\beta$ values were also observed.
In this study, geo-electric strike variations were determined by the analysis of the low frequency MT data (1-1000 s), because regional strike orientations were targeted rather than local inhomogeneities. Dominant strike variations are depicted as rose diagrams in Fig. 2. Geoelectric strike orientation of $\mathrm{N} 85^{\circ} \mathrm{E}$ found in the NAF region coincides well with the geological strike. Overall, orientations demonstrate that the structural complexity increases while moving toward south. The data that show most oblique orientations are the ones in the vicinity of the Çankırı Basin and Kızılırmak Fault Zone with N75 ${ }^{\circ}$. For a long MT profile, such as this case, dimensionality analyses demonstrate that 3-D approximation is required to prevent information loss or producing erroneous models.

\section{Modeling}

Even though it is considered to be more challenging in computational time and memory, 3-D modeling of profile-based MT data has been proven to give more accurate results compared to 2-D interpretation (Siripunvaraporn et al. 2005). In this study, a nonlinear-conjugategradients-based algorithm, ModEM (Kelbert et al. 2014), 


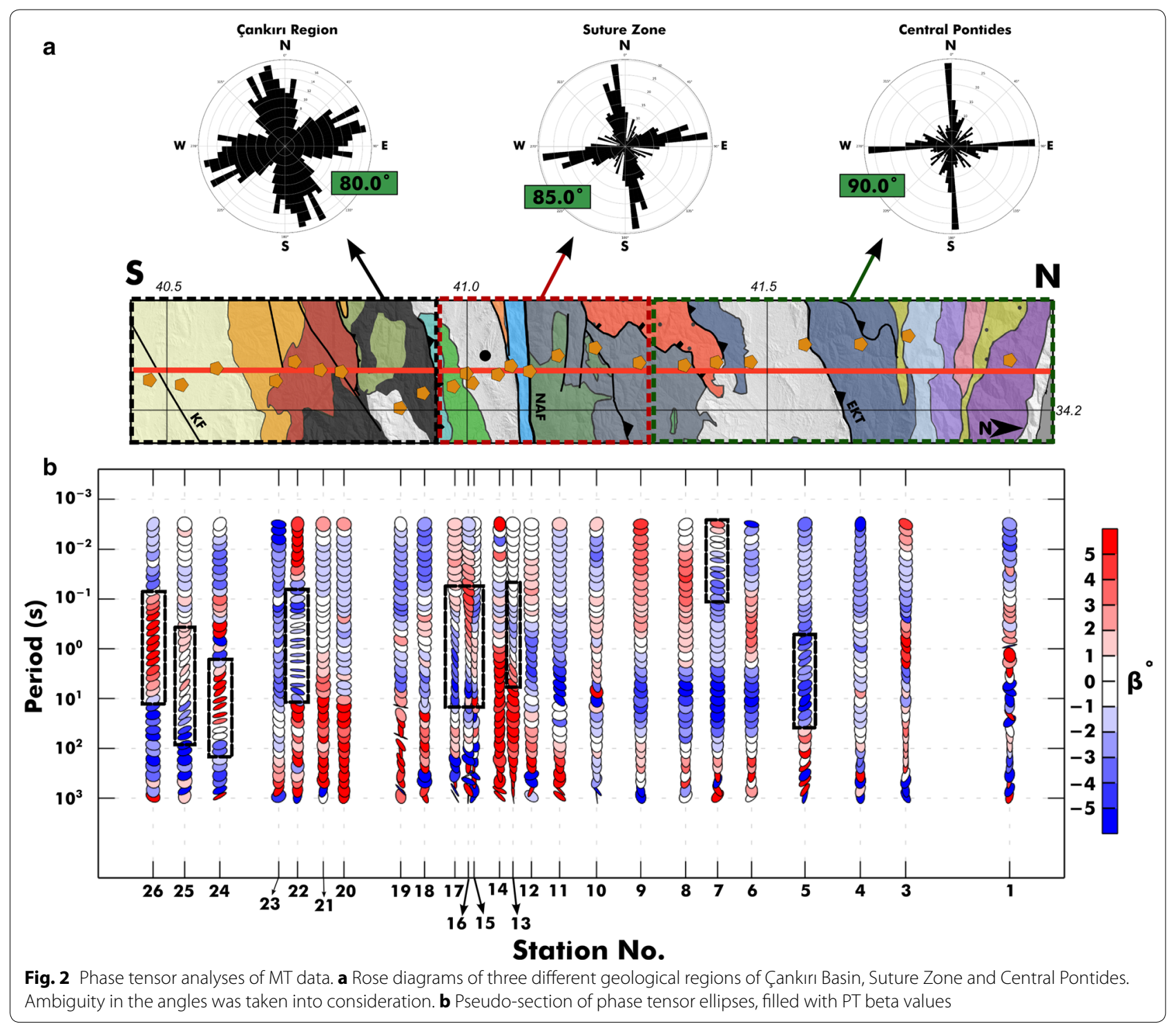

was used for 3-D inverse modeling. Two experiments were designed with two different meshes for the inversions: (1) an experiment designed to analyze the overall regional resistivity variations and the deeper structure (regional model) and (2) a second experiment focused on the shallower structure (down to first $10 \mathrm{~km}$ ) with the stations in the vicinity of the NAF (NAF model). While the first experiment contains the frequency range of 160 $0.001 \mathrm{~Hz}$, shallower model only uses frequencies down to $0.035 \mathrm{~Hz}$. Rectangular grids were designed for both regional and the NAF model, where any overlap of stations was inhibited and boundaries were placed far away from the core of the mesh. Effect of the Black Sea was inserted in the regional model as fixed $0.3 \Omega \mathrm{m}$-valued cells during the inversion down to $\sim 2 \mathrm{~km}$. Rest of the initial model was assigned with $100 \Omega \mathrm{m}$-valued cells.
During the modeling, different Lagrange multipliers, data and model covariance matrices were utilized to observe the effect of regularization and influence of constraints put on impedance elements. By performing these experiments, we wanted to produce a geologically conservative output as well as an earth model that represents a numerically accurate subsurface environment. For the final modeling scheme, a full-tensor inversion was carried out and error floors were selected as $5 \%$ of $\sqrt{Z_{x y} Z_{y x}}$ for every element of the impedance. Tipper data were not included in the inversions due to their noisy state at some stations. Initial trade-off parameter was selected as 30.0, and this value was set up to decrease by a factor of 5.0 when the difference between the RMS values gets low as 0.002 in order not to got stuck in a local minimum. We also implemented an anisotropic model covariance 
matrix that was set to slightly rougher smoothing factor in the direction of the profile $(\mathrm{N}-\mathrm{S})$. The final model was attained with a RMS of 3.52. Same configurations were made for the inversions of the NAF model, too, with the exception of using anisotropic model covariance matrix. The NAF model was generated with a final RMS of 2.02. The output of the regional and the NAF model resembles each other to a certain extent. The main differences between the models are mostly in values of the resistive parts due to selection of different frequency ranges and mesh sizes. Sensitivity tests were applied to these models in order to determine the validity of some conductors (see Additional file 1).

\section{Results and discussion}

On our models, NTOM was depicted as a heterogeneous conductive feature placed with a low-angle discontinuity (Fig. 4a). The southern side of the İAES is dominated by a buried thrust belt (Kaymakçı et al. 2009), where the major thrust faults within the area were identified with northwardly dipping resistive-conductive interfaces. Following the descriptions of Kaymakçı et al. (2009), conductive feature denoted as $C_{1}$ in Fig. $4 \mathrm{~b}$ possibly corresponds to southwards extension of NTOM (encountered in the exploration well) and overlying marine sediments. Southernmost end of $C_{1}$ anomaly might refer to İncik Formation (IF), which was seemingly ascended through this thrusting regime, while footwall-counterpart exists as a much thicker conductive feature. North of $C_{1}$, volcanic unit Yaylaçayı Formation (YF) is visible as a resistive feature, over-thrusting the whole sequence (Fig. 4b).

Çankırı Basin matches with heterogeneously distributed conductive features, which are located south of the thrust belt. Beneath the Çankırı Basin, there is an explicitly conductive anomaly $\left(C_{2}\right)$ (Figs. $3,4 \mathrm{~b}$ ) indicating a fluid-bearing area. The projected hypocenters distributed around $C_{2}$ anomaly support the idea that earthquakes could nucleate on the resistive-conductive interfaces (Gürer and Bayrak 2007). This situation advocates that a fluid-bearing $C_{2}$ has a rheologically sound response in the area. In the vicinity of Çankırı Basin, both the high PT ellipticities observed at all stations (Fig. 2) and scattered seismicity (Fig. 4b) point out a widespread distribution of faults rather than a single localized fault line for the Kizılırmak Fault.

North of the IAES, Tosya Basin appears as a clear conductive syncline between the resistive units of Kunduz and Kösdağ formations (Fig. 4a). Beneath the Tosya Basin, a resistive body $\left(R_{1}:>1000 \Omega \mathrm{m}\right)$ is apparent, covering a large spatial span in the area. $R_{1}$ merges with the surface exposure of the Kösdağ Arc, which is described by a major anticline in the resistivity models (Figs. 3, 4a, b) as previously claimed by Aygül et al. (2015). Large angle of the anticline suggests that the area was overturned under great compressional stress. Moreover, the voluminous nature of $R_{1}$ is reasonable within the evolutionary context of supra-subduction environment in the region (Kaymakçı et al. 2009; Aygül et al. 2015), which led to development of the initial intra-oceanic arc stage and following collision of oceanic crust with the arc during the convergence of Kırșehir Block and Sakarya Continent.

The conductive environment just north of the NAF coincides with the ophiolitic melange units of Kirazbaș Formation (KBF) placed below $\sim 5 \mathrm{~km}$ (Fig. 4b). In deeper structure, $R_{1}$ is in tectonic contact with relatively lower resistive zone $\left(R_{2}:>150 \Omega \mathrm{m}\right)$ made up of large metamorphic sole of the CPS (Figs. 3, 4b). The upper portion of the CPS $(<5 \mathrm{~km})$ comprises of relatively heterogeneous and conductive features, while these features morph into a resistive body at depth. The resistivity contrast between $R_{1}$ and $R_{2}$, on both sides of the NAF, clearly illustrates the effect of $85 \mathrm{~km}$ offset (Hubert-Ferrari et al. 2002). Southern portion of Çangaldağ Complex $\left(R_{3}\right)$ appears as a highly resistive body at the tip of CPS $\left(R_{2}\right)$ (Figs. 3, 4). Beneath the northern exposure of the complex, there is an unexpectedly large conductive feature, denoted as $C_{3}$ (Fig. 4b), in which sensitivity tests affirm its location (see Additional file 1).

Fluid intrusion into fault zones changes the required shear stress to exceed fault's stick-slip frictional instability by reducing effective normal stress and causing over-pressurization in the brittle seismogenic portions of the faults. There are several models proposing that the earthquake generation on faults is associated with episodic fluid-related over-pressurization mechanisms in accordance with constant stress accumulation (e.g., Rice 1992; Byerlee 1993). In addition, fluid content within the ductile lower-crust beneath the seismogenic zone was suggested as a controlling parameter on seismicity with mechanisms such as fault-valve behavior (Sibson 1992; Jiracek et al. 2007; Becken and Ritter 2012). Analogously, lack of fluids in the vicinity of faults can infer to near hydrostatic pore pressures that may lead to longer times of stress accumulation and larger rupture events. Previously, MT measurements made on locked strikeslip faults demonstrated a characteristic portrayed by the presence of resistive bodies at both sides of the fault (e.g., Unsworth et al. 1999; Goto et al. 2005; Tank et al. 2003; Tank 2012; Karaş et al. 2017). Both the metamorphic units of CPS $\left(R_{2}\right)$ and mafic units south of the NAF $\left(R_{1}\right)$ can be interpreted as reasonable geological bodies to resist such inclusion of fluids due to their low porosity values or poor interconnection between their pores. Lack of fluids within the area was also imaged with lower $V_{\mathrm{p}} / V_{\mathrm{s}}$ values (Profile 9 of Yolsal-Çevikbilen et al. 2012). 
a

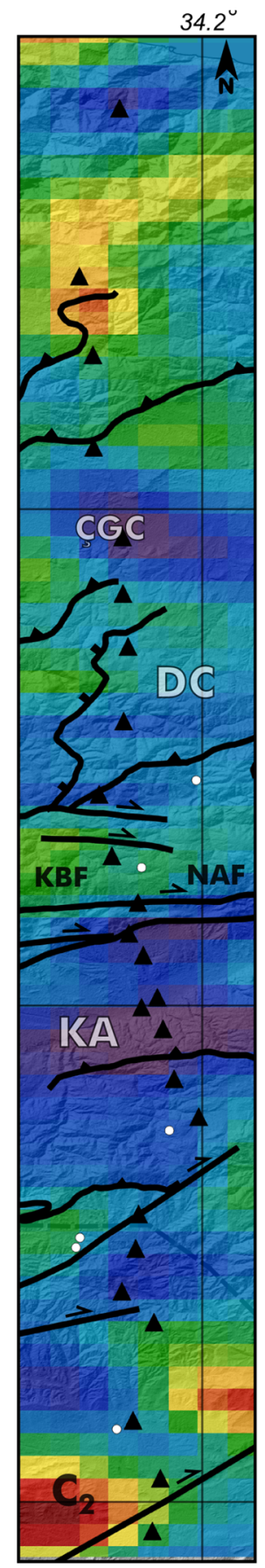

Faults

Lormal Faults

L Thrust Faults b

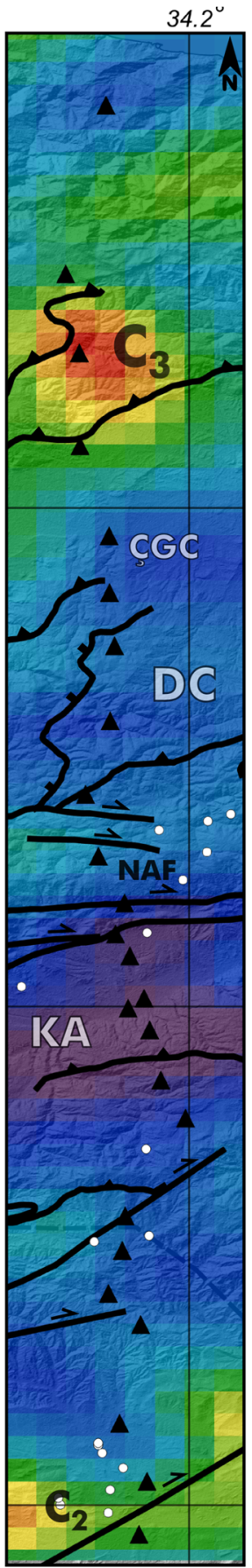

$0 \quad 5 \quad 10 \mathrm{~km}$

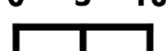

C
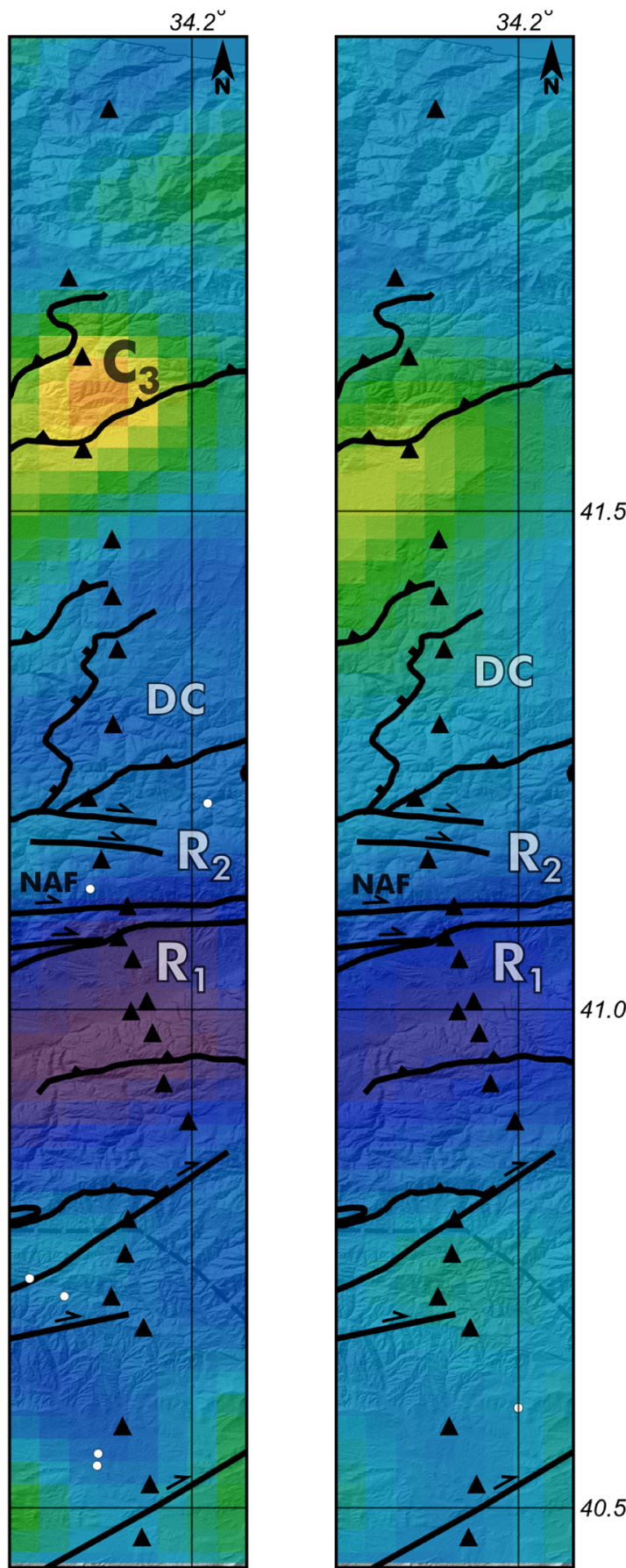

$41.5^{\circ}$
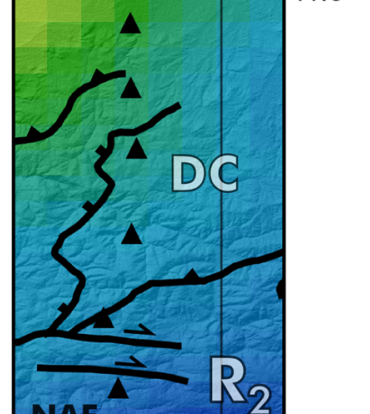

NAF
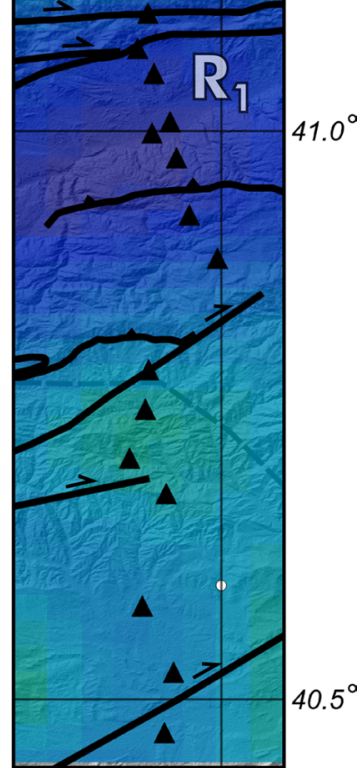

Resistivity ( $\mathbf{\Omega . m}$ )

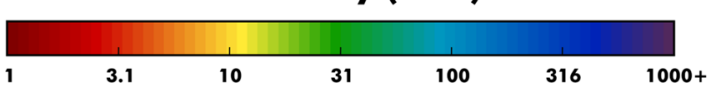

- Earthquake Hypocenters

Fig. 3 Map view of regional resistivity model for depth slices a $6 \mathrm{~km}, \mathbf{b} 10 \mathrm{~km}, \mathbf{c} 15 \mathrm{~km}$, d $20 \mathrm{~km}$. ÇGC Çangaldă̆ Complex. White dots represent the

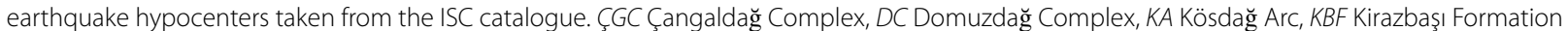




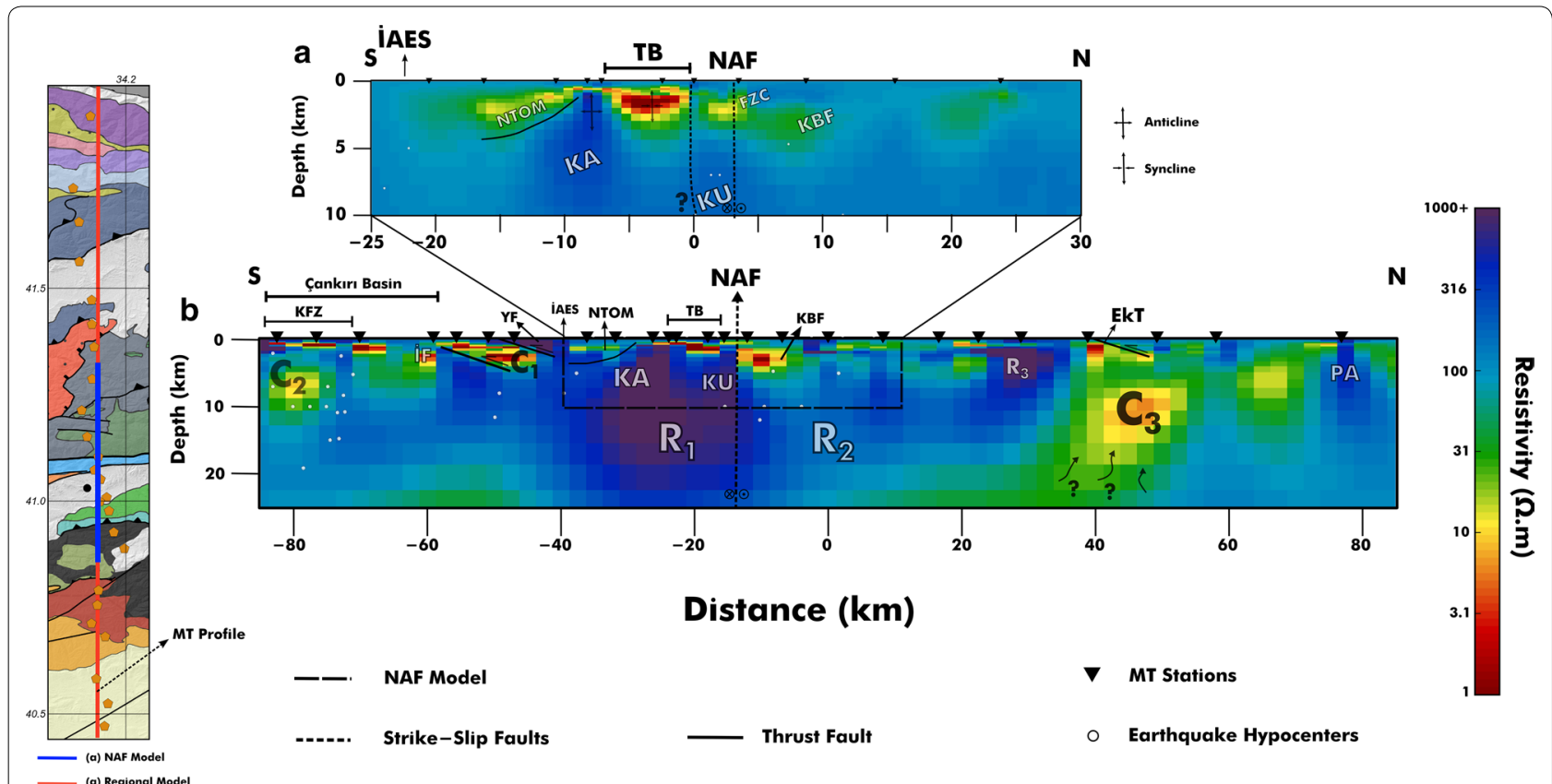

Fig. 4 Cross sections from the $\mathbf{a}$ regional and $\mathbf{b}$ NAF model with interpretation. White dots represent the earthquake hypocenters taken from the ISC catalogue, IAES İzmir-Ankara-Erzincan Suture, EkT Ekinveren Thrust IF İncik Formation, KA Kösdağ Arc, KU Kunduz Unit, KBF Kirazbaşı Formation, KFZ Kızlırmak Fault Zone, NAF North Anatolian Fault, NTOM Neo-Tethyan Ophiolitic Melange, PA Pontide Arc, TB Tosya Basin, YF Yaylaçayı Formation

Earlier MT studies suggest that lower-crustal zones exhibit relatively conductive environments with respect to seismogenic brittle crust (Jiracek et al. 2007). Furthermore, maybe the most prominent characteristic of the NAF in the study area is how the resistive features stretch to such a great extent of depth, pointing out a deeper brittle to ductile transition, thus wider rupture width for potential large events such as the 1668 and 1943 earthquakes (Hubert-Ferrari et al. 2002). Peyret et al. (2012) found that the locking depth in the study area gradually increases from 15 to $25-30 \mathrm{~km}$ between the longitudes of $\mathrm{N} 34.20^{\circ} \mathrm{E}$ and $\mathrm{N} 34.50^{\circ} \mathrm{E}$. MT profile collected in this study crosses the NAF at $\mathrm{N} 34.15^{\circ} \mathrm{E}$, but causative geological features that ensure a mechanically strong base (Kargı Massif and Kösdağ Formation) converge together between these determined intervals. Existence of feldspar-rich mafic minerals of Kösdağ Formation and oceanic material in the vicinity of the NAF might also infer to the deeper lower-crust exposure, since the transition from brittle to ductile behavior requires higher temperature for feldspar minerals (Scholz 1988). Study of Miller (2002) suggests that, without the fluid-assisted weakening, faults cannot fail solely from a stick-slip event beneath $15 \mathrm{~km}$. Following this analogy, lack of fluids within the region might explain why the 1943 Earthquake followed such a large rupture and could not be nucleated at the center of the bend. Deeper investigation with longer-period instruments and better spatial resolution is needed in the area to make further assessments on the structure beneath the seismogenic zone.

In active tectonic settings, existence of large conductive zones in the mid-crustal depths, similar to $C_{3}$, is usually associated with aqueous saline fluids or partial melts (Unsworth 2010). Similar kind of large zones of fluidfilled structures were detected by numerous MT studies (e.g., Tank et al. 2005; Wannamaker et al. 2009; Becken et al. 2011). While the presence of an active source for a partial melt zone (e.g., subduction, delamination) is highly unlikely due to irresponsive heat flow data (Tezcan 1995); a secondary mechanism might have taken a role in production of this conductive anomaly. A probable source is a fluid-enriched lower-crust. This remains as an attractive option because conductive anomaly $C_{3}$ is situated in the forearc region, which is prone to hydration via serpentinized mantle (Hyndman and Peacock 2003). The opening of the lithospheric window accompanied by the southward retreat of the Neo-Tethyan slab (Espurt et al. 2014) may have caused the dehydration of mantle serpentinite via re-heating and initiated the migration of fluid-rich material to the shallower depths beneath the Pontide forearc. Conductive lower-crustal zone was also found within the Eastern Pontides by magnetotelluric studies (Türkoğlu et al. 2008), which could be the product of similar tectonic processes. However, because 
of the profile-based measurement of MT data, it remains ambiguous whether this conductive zone is elongated within the forearc region or only localized in the measured area. Figuring out the source of these fluid-bearing zones might elucidate the tectonic heterogeneity in postcollisional environment for the region and the NAF.

\section{Conclusion}

Three-dimensional resistivity models were produced to determine the crustal structure in North-Central Turkey and its tectonic inferences. Beneath the Çankırı Basin (ÇB), a conductive anomaly was depicted, where the seismicity tends to be scattered around it. High phase tensor ellipticities and widespread seismicity observed within the basin suggest that Kizılırmak Fault Zone might have been distributed as several fault branches rather than a single localized fault line. Thrust belt situated at the North of ÇB was imaged with northwardly dipping resistive-conductive interfaces accurately differentiated through their lithological properties. Resistive body south of the NAF was interpreted as the tectonic amalgamation of emplaced oceanic material and intraoceanic Kösdağ Arc, while on the other side of the fault CPS shows itself as a convex-shaped resistive feature. Both sides of the NAF were imaged with resistive units that reach out to excessive depths. This feature points out fluid deprived upper crust, which matches well with the observed deeper brittle-ductile transition in the area. Lack of fluids in the area might be considered as a valid property, why large earthquakes do not nucleate at the central bend of the segment. At Central Pontides, a large mid-crustal fluid-filled conductive anomaly was imaged. The source of this anomaly was interpreted to be a fluidenriched lower-crustal region that experienced prograde metamorphism.

\section{Additional file}

Additional file 1. Supplementary materials.

\section{Authors' contributions}

SÖ participated in the design of the study, performed statistical analysis and helped draft the manuscript. SBT collected data, participated in the design of the study, performed statistical analysis and helped draft the manuscript. MK helped draft the manuscript. All authors read and approved the final manuscript.

\section{Author details}

${ }^{1}$ Kandilli Observatory and Earthquake Research Institute, Boğaziçi University, Istanbul, Turkey. ${ }^{2}$ Department of Geophysics, Faculty of Mines, Istanbul Technical University, Istanbul, Turkey.

\section{Acknowledgements}

We thank Erşan Türkoğlu and two other anonymous reviewers for their constructive input on the development of this paper. This research was funded by National Science Foundation (of the USA) and is part of the CD-CAT project. We would like to thank Gary Egbert for providing 3-D magnetotelluric inversion code, ModEM. The code package MTpy was used in this study for PT imaging (Krieger and Peacock 2014). We also would like to thank Semih Ergintav for providing relocated earthquakes of ISC catalogue. We also thank the people who contributed to the collection of the MT data.

\section{Competing interests}

The authors declare that they have no competing interests.

Ethics approval and consent to participate Not Applicable.

\section{Publisher's Note}

Springer Nature remains neutral with regard to jurisdictional claims in published maps and institutional affiliations.

Received: 12 December 2017 Accepted: 14 March 2018

Published online: 21 March 2018

\section{References}

Avşar Ü, Türkoğlu E, Unsworth M, Çăglar I, Kaypak B (2013) Geophysical images of the North Anatolian Fault zone in the Erzincan Basin, eastern Turkey, and their tectonic implications. Pure Appl Geophys 170(3):409-431

Aygül M, Okay Al, Oberhänsli R, Schmidt A, Sudo M (2015) Late Cretaceous infant intra-oceanic arc volcanism, the Central Pontides, Turkey: petrogenetic and tectonic implications. J Asian Earth Sci 111:312-327

Becken M, Ritter O (2012) Magnetotelluric studies at the San Andreas Fault Zone: implications for the role of fluids. Surv Geophys 33(1):65-105

Becken M, Ritter O, Bedrosian PA, Weckmann U (2011) Correlation between deep fluids, tremor and creep along the central San Andreas fault. Nature 480(7375):87-90

Booker JR (2014) The magnetotelluric phase tensor: a critical review. Surv Geophys 35(1):7-40

Bürgmann R, Dresen G (2008) Rheology of the lower crust and upper mantle: evidence from rock mechanics, geodesy, and field observations. Annu Rev Earth Planet Sci 36(1):531-567

Byerlee JD (1993) Model for episodic flow of high-pressure water in fault zones before earthquakes. Geology 21(4):303-306

Çakır Z, Akoglu AM, Belabbes S, Ergintav S, Meghraoui M (2005) Creeping along the Ismetpasa section of the North Anatolian fault (Western Turkey): rate and extent from InSAR. Earth Planet Sci Lett 238(1):225-234

Caldwell TG, Bibby HM, Brown C (2004) The magnetotelluric phase tensor. Geophys J Int 158(2):457-469

Ergintav S, Reilinger RE, Çakmak R, Floyd M, Cakir Z, Doğan U, King RW, McClusky S, Özener H (2014) Istanbul's earthquake hot spots: geodetic constraints on strain accumulation along faults in the Marmara seismic gap. Geophys Res Lett 41(16):5783-5788

Espurt N, Hippolyte JC, Kaymakci N, Sangu E (2014) Lithospheric structural control on inversion of the southern margin of the Black Sea Basin, Central Pontides, Turkey. Lithosphere 6(1):26-34

Goto TN, Wada Y, Oshiman N, Sumitomo N (2005) Resistivity structure of a seismic gap along the Atotsugawa Fault, Japan. Phys Earth Planet Inter 148(1):55-72

Gürer A, Bayrak M (2007) Relation between electrical resistivity and earthquake generation in the crust of West Anatolia, Turkey. Tectonophysics 445(1):49-65

Hubert-Ferrari A, Armijo R, King G, Meyer B, Barka A (2002) Morphology, displacement, and slip rates along the North Anatolian Fault, Turkey. J Geophys Res Solid Earth 107(B10):2235

Hyndman RD, Peacock SM (2003) Serpentinization of the forearc mantle. Earth Planet Sci Lett 212(3):417-432

Jiracek GR, Gonzalez VM, Grant Caldwell T, Wannamaker PE, Kilb D (2007). Seismogenic, electrically conductive, and fluid zones at continental plate boundaries in New Zealand, Himalaya, and California, USA. A continental plate boundary: tectonics at South Island, New Zealand, pp 347-369

Karabacak V, Altunel E, Cakir Z (2011) Monitoring aseismic surface creep along the North Anatolian Fault (Turkey) using ground-based LIDAR. Earth Planet Sci Lett 304(1-2):64-70 
Karaş M, Tank SB, Özaydın S (2017) Electrical conductivity of a locked fault: investigation of the Ganos segment of the North Anatolian Fault using three-dimensional magnetotellurics. Earth Planets Space 69(1):107. https://doi.org/10.1186/s40623-017-0695-2

Kaya T, Tank SB, Tunçer MK, Rokoityansky II, Tolak E, Savchenko T (2009) Asperity along the North Anatolian Fault imaged by magnetotellurics at Düzce, Turkey. Earth Planets Space 61(7):871-884. https://doi.org/10.1186/ BF03353198

Kaya T, Kasaya T, Tank SB, Ogawa Y, Tunçer MK, Oshiman N, Honkura Y, Matsushima M (2013) Electrical characterization of the North Anatolian Fault Zone underneath the Marmara Sea, Turkey by ocean bottom magnetotellurics. Geophys J Int 193(2):664-677

Kaymakçı N, Özçelik Y, White SH, Van Dijk PM (2009) Tectono-stratigraphy of the Çankırı Basin: late Cretaceous to early Miocene evolution of the Neotethyan suture zone in Turkey. Geol Soc Lond Spec Publ 311(1):67-106

Kelbert A, Meqbel N, Egbert GD, Tandon K (2014) ModEM: a modular system for inversion of electromagnetic geophysical data. Comput Geosci $66: 40-53$

Krieger L, Peacock JR (2014) MTpy: a Python toolbox for magnetotellurics. Comput Geosci 72:167-175

Miller SA (2002) Inferring fault strength from earthquake rupture properties and the tectonic implications of high pore pressure faulting. Earth Planets Space 54(11):1173-1179. https://doi.org/10.1186/BF03353318

Okay Al, Sunal G, Sherlock S, Altner D, Tüysüz O, Kylander-Clark AR, Aygül M (2013) Early Cretaceous sedimentation and orogeny on the active margin of Eurasia: Southern Central Pontides, Turkey. Tectonics 32(5):1247-1271

Örgülü G (2011) Seismicity and source parameters for small-scale earthquakes along the splays of the North Anatolian Fault (NAF) in the Marmara Sea. Geophys J Int 184(1):385-404

Parsons T, Toda S, Stein RS, Barka A, Dieterich JH (2000) Heightened odds of large earthquakes near Istanbul: an interaction-based probability calculation. Science 288(5466):661-665

Peyret M, Masson F, Yavasoglu H, Ergintav S, Reilinger R (2012) Present-day strain distribution across a segment of the central bend of the North Anatolian Fault Zone from a Persistent-Scatterers InSAR analysis of the ERS and Envisat archives. Geophys J Int 192(3):929-945

Rice JR (1992) Fault stress states, pore pressure distributions, and the weakness of the San Andreas fault. Int Geophys 51:475-503

Ritter O, Hoffmann-Rothe A, Bedrosian PA, Weckmann U, Haak V (2005) Electrical conductivity images of active and fossil fault zones. Geol Soc Lond Spec Publ 245(1):165-186

Scholz CH (1988) The brittle-plastic transition and the depth of seismic faulting. Geol Rundsch 77(1):319-328

Şengör AMC, Tüysüz O, İmren C, Sakınç M, Eyidoğan H, Görür N, Le Pichon X, Rangin C (2005) The North Anatolian fault: a new look. Annu Rev Earth Planet Sci 33:37-112
Sibson RH (1992) Implications of fault-valve behaviour for rupture nucleation and recurrence. Tectonophysics 211(1-4):283-293

Sibson RH (2014) Earthquake rupturing in fluid-overpressured crust: how common? Pure Appl Geophys 171(11):2867-2885

Siripunvaraporn W, Egbert G, Uyeshima M (2005) Interpretation of two-dimensional magnetotelluric profile data with three-dimensional inversion: synthetic examples. Geophys J Int 160(3):804-814

Stein RS, Barka AA, Dieterich JH (1997) Progressive failure on the North Anatolian fault since 1939 by earthquake stress triggering. Geophys J Int 128(3):594-604

Tank SB (2012) Fault zone conductors in Northwest Turkey inferred from audio frequency magnetotellurics. Earth Planets Space 64(9):729-742. https:// doi.org/10.5047/eps.2012.02.001

Tank SB, Honkura Y, Ogawa Y, Oshiman N, Matsushima M, Celik C, Isikara M (2003) Resistivity structure in the western part of the fault rupture zone associated with the 1999 Izmit earthquake and its seismogenic implication. Earth Planets Space 55(7):437-442. https://doi.org/10.1186/ BF03351777

Tank SB, Honkura Y, Ogawa Y, Matsushima M, Oshiman N, Tunçer MK, Çelik C, Tolak E, Issıkara AM (2005) Magnetotelluric imaging of the fault rupture area of the 1999 Izmit (Turkey) earthquake. Phys Earth Planet Inter 150(1):213-225

Tezcan AK (1995) Geothermal explorations and heat flow in Turkey. Terr Heat Flow Geotherm Energy Asia, pp 23-42

Türkoğlu E, Unsworth M, Çağlar I, Tuncer V, Avşar Ü (2008) Lithospheric structure of the Arabia-Eurasia collision zone in eastern Anatolia: magnetotelluric evidence for widespread weakening by fluids? Geology 36(8):619-622

Türkoğlu E, Unsworth M, Bulut F, Çağlar I (2015) Crustal structure of the North Anatolian and East Anatolian Fault Systems from magnetotelluric data. Phys Earth Planet Inter 241:1-14

Unsworth M (2010) Magnetotelluric studies of active continent-continent collisions. Surv Geophys 31(2):137-161

Unsworth M, Egbert G, Booker J (1999) High-resolution electromagnetic imaging of the San Andreas fault in central California. J Geophys Res Solid Earth 104(B1):1131-1150

Wannamaker PE, Caldwell TG, Jiracek GR, Maris V, Hill GJ, Ogawa Y, Bibby HM, Bennie SL, Heise W (2009) Fluid and deformation regime of an advancing subduction system at Marlborough, New Zealand. Nature 460(7256):733

Yolsal-Çevikbilen S, Biryol CB, Beck S, Zandt G, Taymaz T, Adiyaman HE, Özacar AA (2012) 3-D crustal structure along the North Anatolian Fault Zone in north-central Anatolia revealed by local earthquake tomography. Geophys J Int 188(3):819-849 